\title{
Recenzja książki: Justyna Maguś, „Słowo Polskie” w latach 1918-1928. Organ prasowy Narodowej Demokracji, Wydawnictwo Uniwersytetu Marii Curie- Skłodowskiej, Lublin 2019, ss. 410
}

K siążka autorstwa Justyny Maguś „Słowo Polskie” w latach 1918-1928. Organ prasowy Narodowej Demokracji ukazała się w roku 2019 nakładem Wydawnictwa Uniwersytetu Marii Curie-Skłodowskiej. Monografia wpisuje się w badania nad prasą Narodowej Demokracji (1886-1939), realizowane na Wydziale Politologii i Dziennikarstwa Uniwersytetu Marii Curie-Skłodowskiej w Lublinie ${ }^{1}$. Przede wszystkim publikacja wzbogaca wiedzę na temat prasowych organów partyjnych Drugiej Rzeczypospolitej. Należy zaznaczyć, że środowisko polityczne Narodowej Demokracji w tym zakresie dominowało względem innych nurtów ideowych. Za istotną część praktyki politycznej uznało bowiem sprawnie funkcjonujący system propagandy. O jego jakości świadczyły: odpowiednia struktura organizacyjna redakcji, segmentacja rynku prasowego pod względem cech społeczno-demograficznych czytelników, ale też ich doświadczenia politycznego i społecznego, wykwalifikowana kadra dziennikarzy, wsparcie merytoryczne naukowców współpracujących z redakcjami, wysoki poziom pisarstwa. W ofercie prasowej Narodowej Demokracji pojawiły się pisma dla mieszkańców wsi i miast, chłopów, robotników, inteligencji, tytuły branżowe i specjalistyczne, ale też pisma przeznaczone dla młodzieży akademickiej oraz kobiet ${ }^{2}$.

1 Dotychczas ukazały się: Prasa Narodowej Demokracji 186-1939, red. A. Dawidowicz, E. Maj, Wyd. UMCS, Lublin 2010, ss. 624; Prasa Narodowej Demokracji, t. 2: Od roku 1939 do początku XXI wieku, red. A. Dawidowicz, E. Maj, Wyd. UMCS, Lublin 2011, ss. 271; Prasa Narodowej Demokracji, t. 3: Publicyści, red. A. Dawidowicz, E. Maj, Wyd. UMCS, Lublin 2012, ss. 343; Prasa Narodowej Demokracji, t. 4: Prasa lokalna, regionalna, środowiskowa, red. A. Dawidowicz, E. Maj, Wyd. UMCS, Lublin 2013, ss. 417; E. Maj, Komunikowanie polityczne Narodowej Demokracji 1918-1939, Wyd. UMCS, Lublin 2010, ss. 631; idem, Political Communication of National Democracy 1918-1939, Lublin 2013, ss. 302.

2 Zob. np. E. Maj, Komunikowanie polityczne Narodowej Demokracji..., s. 570-575; A. Dawidowicz, Specyficzne cechy i funkcje prasy Narodowej Demokracji (1893-1939), [w:] Państwo nie- 
Przedmiotem badań recenzowanej publikacji jest jeden z najpopularniejszych lwowskich dzienników „Słowo Polskie”, wychodzący pod auspicjami Narodowej Demokracji od 1902 r. Jak zauważyła autorka, szczególne zainteresowanie wzbudzał on wśród inteligencji (s. 34-35). Jarosław Jarowiecki wskazał, że „na gruncie lwowskim było to pismo najbardziej europejskie"4. W gronie jego publicystów znaleźli się główni ideolodzy narodowi oraz twórcy Narodowej Demokracji - Roman Dmowski, Jan Ludwik Popławski, ale też działacze polityczni, m.in.: Stanisław Grabski, Stanisław Kozicki, Roman Rybarski, Zygmunt Wasilewski, poeci i naukowcy ${ }^{5}$.

Początkowa cezura badawcza była związana z odzyskaniem przez Polskę niepodległości w 1918 r. Należy wskazać, że w okresie I wojny światowej praca redakcji „Słowa Polskiego" została zawieszona. Pismo reaktywowano po trzech latach przerwy w 1918 r., choć aż do połowy 1919 r. nie przypominało dawnej edycji zarówno pod względem jakościowym, jak i technicznym. Ten stan rzeczy uległ zmianie po subwencji od ziemianina Zygmunta Aleksandra Skarbka ${ }^{6}$. W książce analizie poddano dziesięć lat funkcjonowania pisma. Autorka badania zakończyła na roku 1928. Klamra zamykająca okres badawczy była właściwa ze względu na ewolucję pisma i zmianę jego linii politycznej oraz przeobrażenia po marcowych wyborach parlamentarnych. Porażka wyborcza doprowadziła do przekształceń w środowisku Narodowej Demokracji, w miejsce Związku Ludowo-Narodowego powołano „nową jakość polityczną w postaci Stronnictwa Narodowego"7.

Dzięki zastosowaniu chronologiczno-problemowego ujęcia tematu autorka uzyskała efekt w postaci kompendium wiedzy o „Słowie Polskim”. Przedstawiła jego ge-

podległe: Twórcy - strategie - komunikacja społeczna, red. A. Dawidowicz, E. Maj, Lublin 2019, s. $140-156$.

3 Stanisław Grabski w pamiętniku wspominał, że „Słowo Polskie” było najpoczytniejszym pismem nie tylko we Lwowie, lecz w całej Galicji, zob. szerzej: S. Grabski, Pamiętniki, t. 1, wstęp i przygot. W. Stankiewicz, Warszawa 1989, s. 175, podobne sformułowania na temat dziennika pojawily się też we wspomnieniach Klaudiusza Hrabyka. Idem, Wspomnienia: część II, „Rocznik Historii Czasopiśmiennictwa Polskiego" 1970, nr 9/3, s. 428.

4 J. Jarowiecki, Studia nad prasą polską XIX i XX wieku, t. 2, Kraków 2006, s. 50.

5 U. Jakubowska, Prasa Narodowej Demokracji w dobie zaborów, Warszawa-Łódź 1988, s. 48.

6 A. Paczkowski, Prasa polska w latach 1918-1939, Warszawa 1980, s. 39.

7 E. Maj. Związek Ludowo-Narodowy 1919-1928. Studium z dziejów myśli politycznej, Lublin 2000, s. 14.

8 Dotychczas problematykę „Słowa Polskiego” podejmowano w szerszych opracowaniach dotyczących prasy lwowskiej lub prasy Narodowej Demokracji w okresie zaborów oraz II Rzeczypospolitej (zob. np. U. Jakubowska, Prasa Narodowej Demokracji w dobie zaborów, Warszawa-Łódź 1988; eadem, Lwów na przełomie XIX i XX wieku. Przegląd środowisk prasotwórczych, Warszawa 1991; A. Lubczyńska, Działalność wydawnicza Narodowej Demokracji w Galicji w dobie autonomii (1892-1914), Pruszcz Gdański 2016; A. Paczkowski, Prasa polska w latach 1918-1939, Warszawa 1980; J. Jarowiecki, Studia nad prasa polska XIX i XX wieku, Kraków 2006; idem, Studia nad prasą polską XIX i XX wieku, t. 2, Kraków 2006; idem, Dzieje prasy polskiej we Lwowie do 1945 roku, Kraków-Wrocław 2008; lub w artykułach podejmujących szczegółowe problemy badawcze, np.: A. Wątor, Rola lwowskiego dziennika „Słowo Polskie” w tworzeniu partii politycznej w początkach XX wieku, [w:] Prasa Naro- 
nezę, uwarunkowania funkcjonowania, zespół redakcyjny, promowane wartości, ale też podejmowaną problematykę. W związku z tym zrekonstruowano również obraz wydarzeń politycznych w badanym okresie Drugiej Rzeczypospolitej, a także specyfikę polskiego rynku prasowego. Zaletą opracowania jest więc klarowna i spójna struktura z wyraźnie zaznaczonym obszarem badawczym.

Recenzowana monografia składa się ze wstępu, pięciu rozdziałów, zakończenia, bibliografii, spisu tabel, wykresów, ilustracji, aneksu (zawierającego przykładowe reklamy oraz ilustracje obecne na łamach pisma, zdjęcia siedziby redakcji) oraz indeksu osobowego. We wstępie autorka uzasadniła podjęcie problematyki, przybliżyła znaczenie pisma jako źródła informacji dla mieszkańców wielokulturowego Lwowa, akcentując różnorodność podejmowanej przez redakcję tematyki. Uwadze badawczej nie umknęła pozycja polityczna Narodowej Demokracji, a więc też uwarunkowania sprzyjające popularyzacji tytułu, choć ten wątek można było jeszcze poszerzyć ${ }^{9}$.

We wstępie autorka uzasadniła decyzję o wykorzystaniu w procesie badawczym metody analizy zawartości, charakterystycznej dla badań medioznawczych. Sformułowała główne pytanie badawcze, dociekając „jaka problematyka dominowała na łamach dziennika w latach 1918-1928, a jaka miała marginalne znaczenie” (s. 10) oraz postawiła cztery szczegółowe hipotezy, wskazując, że: 1. „Stanisław Grabski częściej niż inni redaktorzy naczelni wykorzystywał szpaltę redakcyjną do promowania myśli narodowodemokratycznej”; 2. „Problematyka dotycząca idei rzadziej występowała na łamach »Słowa Polskiego « niż pozostałe zagadnienia mające wymiar bieżących spraw politycznych, społecznych, wyznaniowych, oświatowych”; 3. „Problematyka mniejszości narodowych była częściej podejmowana przez członków redakcji w artykułach wstępnych niż pozostałe, wyodrębnione w strukturze problemy”; 4. „Tematyka dotycząca sytuacji wewnętrznej w państwie dominowała w przekazach nadawcy nad zagadnieniami dotyczącymi spraw międzynarodowych" (s. 10).

W rozdziale pierwszym autorka wyszczególniła cechy charakterystyczne dla systemu prasowego Narodowej Demokracji, odnosząc się do etapów jego powstawania,

dowej Demokracji (1886-1939), red. A. Dawidowicz, E. Maj, Lublin, 2010, s. 129-142; W. Wojdyło, Rola lwowskiego "Stowa Polskiego" w propagowaniu idei endeckiej w Małopolsce Wschodniej, [w:] Prasa Narodowej Demokracji (1886-1939), red. A. Dawidowicz, E. Maj, Lublin, 2010, s. 143-149; E. Wójcik, Organizacja i działalność lwowskiej Spółki Wydawniczej „Słowa Polskiego” (1895-1938), „Rocznik Historii Prasy Polskiej”, t. XVII (2014), z. 1, s. 25-44; A. Lubczyńska „Tygodnik Słowa Polskiego. Bezpłatny dodatek niedzielny do »Słowa Polskiego « poświęcony nauce, literaturze i sztuce" (1902-1903), „Rocznik Historii Prasy Polskiej”, t. XX (2017), z. 2, s. 73-89.

9 Po wyborach do Sejmu Ustawodawczego w 1919 r. zrzeszający narodowych demokratów Związek Sejmowo-Ludowo-Narodowy był najliczniejszym z klubów. Podobnie było po wyborach do Sejmu I kadencji w 1922 r. Wówczas blok Chrześcijański Związek Jedności Narodowej uzyskał 169 mandatów (w tym 98 mandatów Związek Ludowo-Narodowy). Przedstawiciele Narodowej Demokracji zasiadali w rządach Ignacego Paderewskiego, Leopolda Skulskiego, Wincentego Witosa, Władysława Grabskiego, Aleksandra Skrzyńskiego. Sytuacja odmieniła się po przewrocie majowym w 1926 r., kiedy to Narodowa Demokracja zaczęła tracić wpływy polityczne. Zob. szerzej, E. Maj, Związek Ludowo-Narodowy..., s. 26-27, 68, 106. 
a także założeń i celów sformułowanych przez założycieli poszczególnych tytułów. Następnie skierowała uwagę na narodowodemokratyczny ruch wydawniczy w Galicji, wskazując pozycję „Słowa Polskiego” wśród innych pism tego środowiska politycznego oraz dokonała szczegółowego przedstawienia historii powstania dziennika, jego twórców, redakcji, publicystów i współpracowników. Autorka uchwyciła zmiany w formule i strukturze pisma, które dokonywały się analogicznie do zmian na stanowisku redaktora naczelnego. Zasadne było wyodrębnienie podrozdziału traktującego o „Słowie Polskim" po 1918 r., a więc ukazującego proces reaktywacji pisma i działalności redakcji w nowych warunkach politycznych, prawnych, społecznych i ekonomicznych. Autorka dokonała opisu adresata pisma, zespołu redakcyjnego, systemu kolportażu, głównych form pozyskiwania informacji, sposobu finansowania, szaty graficznej i stałych rubryk, dodatków okolicznościowych. W książce przedstawiono też wyniki badań nad częstotliwością występowania w artykułach odredakcyjnych kategorii tematów, tj.: idee, sprawy wewnętrzne, sprawy zagraniczne, mniejszości narodowe, sprawy redakcyjne (s. 49-50), wskazując na przewagę tematyki dotyczącej spraw wewnętrznych, co uzasadniła troską redakcji „o los nowo odrodzonego państwa oraz przynależność regionu do terytorium narodowego Rzeczypospolitej Polskiej" (s. 50).

W rozdziale drugim autorka zaprezentowała katalog wartości politycznych propagowanych na łamach „Słowa Polskiego", tj.: naród, państwo narodowe, samowystarczalna gospodarka. Skonfrontowała w tym wymiarze założenia ideowe Narodowej Demokracji z pracą redakcyjną dziennika, wspomagającą promocję wartości narodowych i rozwiązań ustrojowych, a także prowadzącą działania edukacyjne i wychowawcze. Już na początku rozdziału autorka wskazała, że: „Lwowski organ narodowodemokratyczny niewiele miejsca poświęcał zagadnieniom teoretycznym, niemniej jednak były one ważnym składnikiem pisma, sytuując go w grupie dzienników o zabarwieniu ideowym" (s. 87).

Rozdział trzeci dotyczył mniejszości narodowych, co było istotne ze względu na wielonarodowy charakter Drugiej Rzeczypospolitej. Tematyka ta była jednym z głównych wątków debaty publicznej, inicjowały ją liczne konflikty narodowościowe. Jak zauważyła autorka, w "Słowie Polskim” koncentrowano się głównie na mniejszościach słowiańskich, przede wszystkim ukraińskiej, mniej białoruskiej, co było związane zarówno z aspiracjami niepodległościowymi Ukraińców, jak i ich liczbą w Galicji Wschodniej. Podejmowano również tematy dotyczące mniejszości żydowskiej oraz niemieckiej i wynikające $\mathrm{z}$ ich działalności zagrożenia dla tożsamości narodowej Polaków oraz odrodzonej państwowości. Autorka w rozdziale zaprezentowała kwestie ogniskujące spory, ich przebieg oraz scenariusze zażegnania konfliktów przedstawiane na łamach dziennika.

$\mathrm{W}$ rozdziale czwartym uwaga autorki skupiła się na najpopularniejszej tematyce przedstawianej w artykułach odredakcyjnych „Słowa Polskiego” - sprawach wewnętrznych Polski. Redakcja dziennika w tym zakresie koncentrowała się na kształtowaniu granic państwa, życiu politycznym oraz ustroju administracyjnym Kresów Wschodnich. Odnoszono się głównie do granicy wschodniej oraz terytoriów będących przedmiotem plebiscytów. W książce można przeczytać, że „publicyści »Słowa Polskiego» 
byli gotowi do aktywizowania czytelników, ukierunkowując ich na kwestie narodowego terytorium Polski. Kreślili optymalny kształt granic państwa, podkreślali dramatyczność sytuacji geograficzno-przestrzennej po zakończeniu Wielkiej Wojny" (s. 191).

W rozdziale piątym autorka ukazała poglądy redakcji „Słowa Polskiego" na temat sytuacji geopolitycznej państwa polskiego, z uwzględnieniem klasycznego podziału na sojuszników i wrogów Polski. Przedmiotem zainteresowania publicystów dziennika były nie tylko państwa, lecz także Liga Narodów. Autorka zwróciła uwagę na intensyfikację przekazu w momencie ważnych wydarzeń politycznych o znaczeniu międzynarodowym.

Dostrzec można, że w procesie przygotowywania monografii została wykorzystana bogata literatura przedmiotu. Dominowały publikacje z zakresu medioznawstwa, politologii oraz historii. Szczegółowa kwerenda objęła zbiory księgarskie dotyczące polskiej prasy politycznej, a szczególnie wydawnictw Narodowej Demokracji.

Walory poznawcze pracy wzmacnia fakt, że autorka przebadała 3543 egzemplarze pisma, co stanowiło 95,1\% wszystkich numerów „Słowa Polskiego” (s. 49). Obszerna próba badawcza umożliwiła sformułowanie wiążących wniosków i realizację zamierzeń badawczych. Autorka w toku badań zweryfikowała trzy hipotezy, z kolei nietrafne okazało się przypuszczenie o dominującej w artykułach odredakcyjnych dziennika problematyki mniejszości narodowych, co autorka wytłumaczyła podejmowaniem tej kwestii na dalszych stronach pisma. Wyniki badań poza ujęciem tekstowym znalazły swoje odzwierciedlenie w tabelach i wykresach. Rozwiązanie to zastosowano w rozdziale pierwszym.

W pracy wykorzystano też pisma polityczne, deklaracje ideowe, korespondencję, memuarystykę, biografie, publicystykę polityczną, twórczość naukową i literacką działaczy oraz sympatyków Narodowej Demokracji, a także materiały statystyczne i źródła prawne. Autorka zrealizowała również kwerendę materiałów archiwalnych w Archiwum Akt Nowych w Warszawie, Centralnym Państwowym Archiwum Historycznym Ukrainy we Lwowie, Archiwum Polskiej Akademii Nauk w Warszawie, Lwowskiej Narodowej Naukowej Bibliotece Ukrainy im. Wasyla Stefanyka we Lwowie, Bibliotece Naukowej Polskiej Akademii Umiejętności i Polskiej Akademii Nauk w Krakowie, w Zakładzie Narodowym im. Ossolińskich we Wrocławiu.

Doktor Justyna Maguś kompleksowo i syntetycznie ukazała charakter i zawartość dziennika „Słowo Polskie”. Na uznanie zasługuje wartość faktograficzna pracy, przystępny styl oraz klarowny język. Monografię można polecić jako lekturę konieczną dla badaczy prasy polskiej, historii Narodowej Demokracji, ale też historii Lwowa i relacji przede wszystkim polsko-ukraińskich. 